\title{
HUBUNGAN ASUPAN LEMAK DENGAN KADAR HS-CRP SERUM PADA MAHASISWA OBES DAN TIDAK OBES DI FAKULTAS KEDOKTERAN UNIVERSITAS SAM RATULANGI MANADO
}

\author{
${ }^{1}$ Fajar Aprilianti \\ ${ }^{2}$ Shirley E.S. Kawengian \\ ${ }^{2}$ Alexander S.L. Bolang \\ ${ }^{1}$ Kandidat Skripsi Fakultas Kedokteran Universitas Sam Ratulangi Manado \\ ${ }^{2}$ Bagian Ilmu Gizi Universitas Sam Ratulangi Manado \\ Email: fajar_aprilianti@yahoo.com
}

\begin{abstract}
Fat consumption is now a growing thing in the notice due to changes lifestyle. Excessive fat will increase the risk of obesity and accounted for heart disease. Fat is the most dense source of energy, which produces $9 \mathrm{kcal} /$ gram with the the total dietary fat consumption which is good for health should be $20-30 \%$ of the total energy needs. High sensitive C-reactive protein (hs $\mathrm{CRP}$ ) is a very sensitive test for the detection of cardiovascular risk, coronary heart disease (CHD). The objective of this study was to examine the association between dietary fat intake and levels of hs CRP among the medical students of the Faculty of Medicine, University of Sam Ratulangi Manado. This study was an analytical cross-sectional design, conducted in November - December 2012 with 59 respondents. Using the Mann Whitney test, the result showed that there was no difference in dietary fat intake of obes and non-obes ( $p=0.85>0.05$ with $\mathrm{z}=-0,19)$. Levels of hs-CRP serum obes and nonobes showed that there was difference $(p=0.00<0.05$ with $\mathrm{z}=-3,55)$. Spearman rank test, the result showed that there was no significant association between dietary fat intake and levels of hs-CRP among the medical students of the Faculty of Medicine, University of Sam Ratulangi. Manado ( $\mathrm{p}=0,61>0,05$ with $\mathrm{r}=0,06$ ).
\end{abstract}

Keywords: Dietary fat intake, hs-CRP levels, CHD, Obesity.

\begin{abstract}
Abstrak: Konsumsi lemak saat ini merupakan hal yang semakin di perhatikan karena perubahan gaya hidup. Lemak yang berlebihan akan meningkatkan obesitas dan menyumbang resiko penyakit jantung. Lemak menghasilkan $9 \mathrm{kkal} / \mathrm{gram}$ dengan konsumsi yang dianjurkan sebanyak $20-30 \%$ dari total kebutuhan energi. High sensitive-C reactive protein (hs-CRP) merupakan uji yang sangat sensitive untuk mendeteksi resiko kardiovaskular,penyakit jantung koroner (PJK). Tujuan dari penelitian ini ialah untuk mengetahui perbedaan antara asupan lemak dengan kadar hs CRP mahasiswa obes dengan tidak obes pada Fakultas Kedokteran Universitas Sam Ratulangi Manado. Desain penelitian ini bersifat analitik dengan pendekatan cross sectional. Penelitian ini dilakukan pada bulan November-Desember 2012 dengan jumlah sampel sebanyak 59 orang. Hasil penelitian perbedaan asupan lemak obes dan non obes menggunakan uji Mann Whitney dengan nilai $\mathrm{p}=0,85>0,05$ menunjukan tidak adanya perbedaan asupan lemak mahasiswa obes dengan tidak obes. Nilai $\mathrm{p}=0,00<0,05$ menunjukan ada perbedaan kadar hs-CRP mahasiswa obes dan tidak obes. Uji Spearman rank dengan nilai $\mathrm{p}=0,61>0.05$ dengan nilai $\mathrm{r}=0,06$ menunjukan ada hubungan positif yang lemah tetapi tidak bermakna antara asupan lemak dengan kadar hs-CRP pada mahasiswa Fakultas Kedokteran Universitas Sam Ratulangi.
\end{abstract}

Kata kunci: Asupan lemak, hs-CRP, PJK, Obesitas. 
Masalah gizi lebih baru muncul di permukaan pada awal tahun 1990-an. Peningkatan pendapatan perkelompok masyarakat tertentu, terutama perkotaan menyebabkan perubahan dalam gaya hidup, terutama pola makan. Pola makan yang berkembang saat ini adalah pola makan yang rendah karbohidrat, rendah serat kasar, dan tinggi lemak sehingga menggeser mutu makanan kearah tidak seimbang. ${ }^{1}$

Asupan lemak selama ini telah dianggap sebagai penyebab utama dari obesitas. Ada beberapa jenis lemak yang memang dianggap sebagai musuh utama obesitas dan penyakit kardiovaskuler, seperti contohnya lemak trans dan lemak jenuh. ${ }^{2}$

Obesitas merupakan suatu akumulasi lemak berlebih di dalam tubuh, akumulasi lemak ini dapat mengganggu kesehatan secara keseluruhan, karena dapat menyebabkan penyakit kardiovaskular, diabetes tipe 2 dan penyakit degeneratif. ${ }^{3}$

Data yang dikumpulkan dari seluruh dunia memperlihatkan bahwa terjadi peningkatan prevalensi Overweight dan Obesitas pada 10 sampai 15 tahun terakhir dengan angka kejadian terbanyak di Amerika. Saat ini diperkirakan sebanyak lebih dari 100 juta penduduk di seluruh dunia menderita Obesitas, dan angka ini masih akan terus meningkat. ${ }^{2}$

Berdasarkan Riset Kesehatan Dasar (Riskesdas) 2007 menunjukkan bahwa $8,8 \%$ orang dewasa berumuæ 15 tahun kelebihan berat dan 10,3 persen gemuk. ${ }^{4}$ Sedangkan pada tahun 2011 jumlah penduduk yang obes meningkat menjadi 11,7\%. Di Sulawesi utara angka kejadian obesitas yang paling tinggi di bandingkan seluruh provinsi lainnya yaitu mencapai 21,9\%. Berdasarkan data tersebut, dapat disimpulkan bahwa Overweight dan Obesitas di Indonesia telah menjadi masalah besar yang memerlukan penanganan secara serius. ${ }^{5}$

Obesitas memiliki hubungan yang erat dengan tingginya kejadian penyakit kardiovaskular, diabetes mellitus, dan penyakit degeneratif. Obesitas dapat meningkatkan kadar trigliserida yang buruk untuk kesehatan jantung dan menurunkan kadar HDL yang bersifat kardioprotektif. Selain itu, seiring meningkatnya obesitas, meningkat juga angka hipertensi. ${ }^{6}$

Pada orang yang menderita obestas dapat diperiksa High sensitive-C reactive protein yang merupakan prediktor risiko penyakit diabetes mellitus tipe 2 , sindroma metabolic, dan penyakit kardiovaskular. Hs-CRP adalah penanda inflamasi yang mencirikan proses aterosklerotik, sindrom metabolik dikaitkan dengan resistensi insulin dan inflamasi sistemik. Gangguan ini dapat timbul sejak usia dini pada orang yang obesitas. ${ }^{7}$

Dalam penelitian terhadap wanita obes yang sehat, High sensitif C-reaktif protein (hs-CRP) terbukti meningkat dalam sindrom metabolik keadaan risiko untuk pengembangan penyakit kardiovaskular dan Diabetes mellitus tipe- $2 .{ }^{8}$

Pada saat sekarang ini, pola makan mahasiswa mengakibatkan gangguan gizi kurang maupun berlebih. Hal ini banyak dipengaruhi oleh pola makan tidak teratur, asupan kalori yang berlebihan baik itu karbohidrat atau lemak serta kurangnya melakukan aktifitas fisik sehingga dapat menimbulkan gizi lebih atau obesitas. ${ }^{9}$ Dari uraian latar belakang tersebut penulis merasa perlu untuk melakukan penelitian tentang hubungan asupan lemak dengan kadar High sensitive-C reactive protein pada mahasiswa di Fakultas Kedokteran Sam Ratulangi Manado.

\section{METODOLOGI}

Jenis penelitian yang digunakan dalan penelitian ini bersifat observasional analitik dengan pendekatan cross sectional (potong lintang), semua data diobservasi/ diukur sekali pada saat yang bersamaan. Penelitian ini dilaksanakan di Fakultas Kedokteran Universitas Sam Ratulangi Manado. Pada bulan November-Desember 2012. Populasi seluruh mahasiswa Fakultas Kedokteran Universitas Sam Ratulangi Manado. Sampel berjumlah 59 orang yang datang pada saat penelitian telah berusia 18 tahun, menandatangani informed consent, sampel tidak sedang sakit atau mengalami 
infeksi. Sampel terdiri dari mahasiswa 30 orang obes dan 29 orang yang tidak obes. Indeks massa tubuh obes diatas 25 dan yang tidak obes berkisar 18,5-22,9 dalam standar WHO untuk Asia Pasifik. Pengumpulan data dilakukan dengan pengukuran antopometri mengukur berat dan tinggi badan sampel. Asupan lemak diperoleh dengan cara mewawancarai sampel memakai kuesioner food recall 24 jam dengan menanyakan makanan yang dikonsumsi dalam 24 jam terakhir. Pengukuran kadar high sensitive c-reactive protein dilakukan dengan pengambilan darah vena sampel kemudian sampel darah tersebut diperiksa di laboratorium dengan menggunakan metode LTIA (Latex Turbidimetry Immunoessay). Pengolahan data untuk mencari hubungan asupan lemak dengan kadar high sensitivity C-reaktive protein, dilakukan pengujian statistik korelasi. Pada tahap pertama dilakukan uji normalitas, dan diperoleh hasil bahwa data cenderung tidak terdistribusi nomal. Untuk itu analisis dilakukan dengan menggunakan uji tidak parametrik yaitu uji Mann Whitney untuk mencari perbedaan rata-rata dan uji Spearman pada tingkat kemaknaan 95\% $(\alpha 0,05)$.

\section{HASIL}

Berdasarkan jenis kelamin diketahui, responden laki-laki sebanyak 30 responden (50.8\%) dan responden perempuan sebanyak 29 responden (49.2\%). Pada kelompok tidak obes berdasarkan jenis kelamin diketahui, responden laki-laki sebanyak 15 responden $(50.8 \%)$ dan responden perempuan sebanyak 14 responden (49.2\%). Sedangkan pada kelompok obes berdasarkan jenis kelamin diketahui, responden laki-laki sebanyak 15 responden (50\%) dan responden perempuan sebanyak 15 responden (50\%).

Jumlah responden terbanyak berada pada usia 21 tahun, yaitu sebanyak 19 responden (32.2\%). Sedangkan jumlah responden yang paling rendah berada pada usia 22 tahun, yaitu sebanyak 4 responden (6.8\%). Pada kelompok tidak obes responden terbanyak berada pada usia 21 tahun, yaitu sebanyak 11 responden (37.9\%) dan jumlah responden yang paling rendah berada pada usia 22 tahun, yaitu 1 responden (3.4\%). Pada kelompok obes responden terbanyak berada pada usia 19 dan 21 tahun, yaitu masing-masing sebanyak 8 responden $(26.7 \%)$ dan jumlah responden yang paling rendah berada pada usia 22 tahun, yaitu 3 responden (10\%)

Berdasarkan tempat tinggal diketahui responden yang bertempat tinggal di Kost yaitu sebanyak 34 responden (57.6\%). Dan yang bertempat tinggal dengan orang tua yaitu sebanyak 25 responden (42.4\%). Pada kelompok tidak-obes diketahui responden yang bertempat tinggal di Kost yaitu sebanyak 20 responden (69\%) dan yang bertempat tinggal dengan orang tua yaitu sebanyak 9 responden (31\%).

Berdasarkan pekerjaan orang tua responden, diketahui orang tua responden terbanyak memiliki pekerjaan PNS yaitu sebanyak 34 responden (57.6\%). Pekerjaan orang tua responden yang paling sedikit adalah Pegawai Swasta dan Petani, masingmasing sebanyak 2 responden (3.4\%).

Pada tabel 5 digambarkan Rata-rata asupan lemak responden sebanyak 54.73 gram $\pm 20,83$ dengan asupan lemak yang terendah adalah 15.3 gram dan yang tertinggi adalah 108 gram. Rata-rata asupan lemak pada responden yang obes sebanyak 54,85 gram $\pm 21,34$ dengan asupan lemak terendah adalah 20,5 gram dan tertinggi sebanyak 108,0 gram. Sedangkan pada responden tidak obes rata-rata asupan lemak sebanyak 54,89 gram $\pm 20,52$ dengan yang terendah sebanyak 15,3 gram dan tertinggi sebanyak 93 gram.

Pada tabel 5 tergambar rata-rata kadar hs-CRP serum responden sebesar 1,32 $\mathrm{mg} / \mathrm{L} \pm 1,87$ dengan kadar terendah 0,2 $\mathrm{mg} / \mathrm{L}$ dan kadar tertinggi $9,5 \mathrm{mg} / \mathrm{L}$. Sedangkan pada responden yang obes terlihat rata-rata kadar hs-CRP serum sebesar $2,01 \mathrm{mg} / \mathrm{L} \pm 0.90$ dengan nilai terendah $0,2 \mathrm{mg} / \mathrm{L}$ dan nilai tertinggi 9,5 $\mathrm{mg} / \mathrm{L}$ dan pada responden tidak obes ratarata kadar hs-CRP serum sebesar 0,62 $\mathrm{mg} / \mathrm{L} \pm 0.70$ dengan kadar terendah 0,1 $\mathrm{mg} / \mathrm{L}$ dan kadar tertinggi 2,6 mg/L. 
Pada tabel 6 distribusi responden berdasarkan kecukupan asupan lemak diperoleh hasil data sebanyak 53 orang (89,9\%) yang kekurangan asupan, sebanyak 5 orang $(8,5 \%)$ responden yang mempunyai asupan lemak cukup dan sebanyak 1 orang $(1,7 \%)$ responden yang mempunyai asupan lemak berlebih. Sedangkan pada responden yang obes diperoleh hasil sebanyak 27 orang (90,0\%) yang kekurangan asupan lemak, sebanyak 2 orang $(6,7 \%)$ yang mempunyai asupan lemak cukup dan 1 orang (3,3\%) yang mempunyai asupan lemak berlebih.

Distribusi responden pada tabel 6 berdasarkan risiko kadar High Sensitivity C-Reactive Protein (hs-CRP) serum terlihat responden yang berisiko rendah sebanyak 37 orang (62,7\%), yang berisiko sedang sebanyak 14 orang $(23,7 \%)$ dan yang berisiko tinggi sebanyak 8 orang $(13,6 \%)$. Berdasarkan karakteristik tersebut terlihat responden terbanyak ialah responden yang memiliki risiko rendah dan responden yang sedikit ialah responden yang memiliki risiko tinggi.

Pada tabel 6 terlihat kadar hs-CRP serum responden obes yang berisiko rendah sebanyak 16 orang (53,3\%), yang berisiko sedang 6 orang $(20,0 \%)$ dan yang berisiko tinggi sebanyak 8 orang (26,7\%). Sedangkan pada tidak obes yang berisiko rendah sebanyak 21 orang (72,4\%) dan berisiko sedang sebanyak 8 orang $(27,6 \%)$.

Tabel 7 dapat dilihat analisis statistik Mann-Whitney asupan lemak pada obes dan tidak obes diperoleh nilai signifikansi sebesar $0,85>\alpha 0,05$. Hal tersebut menandakan bahwa tidak terdapat perbedaan ratarata pada asupan lemak obes dan tidak obes. Hasil analisa statistic Mann-Whitney pada tabel 7 kadar hs-CRP serum obes dan tidak obes diperoleh nilai signifikasi sebesar $0,00<\alpha=0,05$. Hal tersebut menandakan bahwa terdapat perbedaan rata-rata antara kadar hsCRP pada obes dan tidak-obes.

Tabel 8 terlihat bahwa dari hasil uji statistik didapatkan nilai koefisien korelasi (r) sebesar 0,06 dan nilai $\rho=0.61>\alpha=0,05$. Hasil ini menunjukkan bahwa tidak ada hubungan yang bermakna antara asupan lemak dengan kadar hs-CRP pada mahasiswa Fakultas Kedokteran Universitas Sam Ratulangi Manado.

Tabel 4. Distribusi karakteristik responden.

\begin{tabular}{|c|c|c|c|c|c|c|c|}
\hline \multirow{2}{*}{\multicolumn{2}{|c|}{ Karakteristik Responden }} & \multirow{2}{*}{$\begin{array}{c}\begin{array}{c}\text { Jumlah } \\
\text { sampel }\end{array} \\
\mathrm{n} \\
\end{array}$} & \multicolumn{3}{|c|}{ Tidak-Obes } & \multicolumn{2}{|c|}{ Obes } \\
\hline & & & $\%$ & $\mathrm{n}$ & $\%$ & $\mathbf{n}$ & $\%$ \\
\hline \multirow{2}{*}{$\begin{array}{c}\text { Jenis } \\
\text { Kelamin }\end{array}$} & Laki-Laki & 30 & 50.8 & 15 & 51.7 & 15 & 50 \\
\hline & Perempuan & 29 & 49.2 & 14 & 48.3 & 15 & 50 \\
\hline \multirow{5}{*}{ Umur } & 18 & 10 & 16.9 & 6 & 20.7 & 4 & 13.3 \\
\hline & 19 & 13 & 22 & 5 & 17.2 & 8 & 26.7 \\
\hline & 20 & 13 & 22 & 6 & 20.7 & 7 & 23.3 \\
\hline & 21 & 19 & 32.2 & 11 & 37.9 & 8 & 26.7 \\
\hline & 22 & 4 & 6.8 & 1 & 3.4 & 3 & 10.0 \\
\hline \multirow{2}{*}{$\begin{array}{l}\text { Tempat } \\
\text { Tinggal } \\
\end{array}$} & Orang Tua & 25 & 42.4 & 9 & 31.0 & 16 & 53.3 \\
\hline & Kost & 34 & 57.6 & 20 & 69.0 & 14 & 46.7 \\
\hline \multirow{5}{*}{$\begin{array}{l}\text { Pekerjaan } \\
\text { Orang tua }\end{array}$} & PNS & 34 & 57.6 & 17 & 58.6 & 17 & 56.7 \\
\hline & Polisi/ABRI & 5 & 8.5 & 1 & 3.4 & 4 & 13.3 \\
\hline & $\begin{array}{c}\text { Pegawai } \\
\text { Swasta }\end{array}$ & 2 & 3.4 & 1 & 3.4 & 1 & 3.3 \\
\hline & Wiraswasta & 16 & 27.1 & 9 & 31.0 & 7 & 23.3 \\
\hline & Petani & 2 & 3.4 & 1 & 3.4 & 1 & 3.3 \\
\hline \multirow[b]{2}{*}{ Status Gizi } & Normal & 29 & 49.2 & & & & \\
\hline & Obes & 30 & 50.8 & & & & \\
\hline
\end{tabular}


Tabel 5. Rata-rata asupan lemak dan kadar hs-CRP serum responden.

\begin{tabular}{|c|c|c|c|c|c|c|}
\hline & \multirow{2}{*}{$\begin{array}{l}\text { Seluruh } \\
\text { sampel }\end{array}$} & \multicolumn{2}{|c|}{ Asupan lemak } & \multirow{2}{*}{$\begin{array}{c}\text { Seluruh } \\
\text { sampel }\end{array}$} & \multicolumn{2}{|c|}{ hs-CRP (mg/L) } \\
\hline & & Obes & Tidak Obes & & Obes & Tidak Obes \\
\hline Rata-rata & 54,73 (g) & 54,85 & 54,89 & 1.32 & 2,01 & 0,62 \\
\hline \pm SD & 20,83 (g) & 21,34 & 20,52 & 1.87 & 0,90 & 0,70 \\
\hline Min & 15,3 (g) & 20,5 & 15,3 & 0.1 & 0.2 & 0.1 \\
\hline Max & $180,0(\mathrm{~g})$ & 108,0 & 93,4 & 9.5 & 9,5 & 2,6 \\
\hline
\end{tabular}

Tabel 6. Kecukupan Asupan lemak dan Risiko kadar hs-CRP serum pada responden.

\begin{tabular}{cccccccc}
\hline & Kategori & Seluruh sampel & $\mathbf{\%}$ & \multicolumn{2}{c}{ Obes } & \multicolumn{2}{c}{ Tidak obes } \\
\cline { 5 - 8 } & & & & $\mathrm{n}$ & $\%$ & $\mathrm{n}$ & $\%$ \\
\hline Asupan lemak & Kurang & 53 & 89,9 & 27 & 90,0 & 26 & 89,7 \\
& Cukup & 5 & 8,5 & 2 & 6,7 & 3 & 10,3 \\
& Lebih & 1 & 1,7 & 1 & 3,3 & - & - \\
\hline Kadar serum & Rendah & 37 & 62,7 & 16 & 53,3 & 21 & 72,4 \\
hs-CRP & Sedang & 14 & 27,3 & 6 & 20,0 & 8 & 27,6 \\
& Tinggi & 8 & 62,7 & 8 & 26,7 & - & - \\
\hline
\end{tabular}

Tabel 7. Perbedaan asupan lemak dan kadar hs-CRP serum responden obes dan tidak obes.

\begin{tabular}{llllll}
\hline & \multicolumn{5}{c}{ Ranks } \\
\cline { 2 - 6 } & Status Gizi & $\mathbf{n}$ & Mean Rank & $\boldsymbol{p}$ & $\mathbf{z}$ \\
\hline asupan lemak & Normal & 29 & 30.43 & & \\
& Obes & 30 & 29.58 & 0,85 & -0.19 \\
& Total & 59 & & & \\
\hline \multirow{2}{*}{ hsCRP } & Normal & 29 & 21.95 & & $-3,55$ \\
& Obes & 30 & 37.78 & 0,00 & \\
& Total & 59 & & & \\
\hline
\end{tabular}

Tabel 8. Hasil Analisis Hubungan asupan lemak dengan kadar hs-CRP.

\begin{tabular}{lll}
\hline Variabel Penelitian & $\boldsymbol{R}$ & $\boldsymbol{p}$ \\
\hline Asupan lemak & 0.06 & 0.61 \\
\hline Hs-CRP & 0.61 \\
\hline
\end{tabular}

Tabel 9. Hasil Analisis Hubungan asupan lemak dengan kadar hs-CRP mahasiswa obes dan tidak obes.

\begin{tabular}{llll}
\hline & Variabel Penelitian & $\boldsymbol{r}$ & $\boldsymbol{p}$ \\
\hline Obes & $\begin{array}{l}\text { Asupan lemak } \\
\text { Hs-CRP }\end{array}$ & 0,01 & 0,94 \\
\cline { 1 - 2 } Tidak obes & $\begin{array}{l}\text { Asupan lemak } \\
\text { Hs-CRP }\end{array}$ & 0,15 & 0,41 \\
\hline
\end{tabular}

Pada tabel 9 hasil uji statistik Spearman didapatkan nilai koefisien korelasi (r) pada obes sebesar 0,01 dan nilai $\rho=0,94>\alpha=0,05$. Hal ini menunjukkan bahwa antara asupan lemak dengan kadar hsCRP pada mahasiswa obes memiliki 
hubungan positif yang lemah tetapi tidak bermakna.

Terlihat pada tabel 9 hasil uji statistic didapatkan nilai koefisien korelasi (r) pada tidak obes sebesar 0,15 dan nilai $\rho=0,41$ $>\alpha=0,05$. Hal ini menunjukkan bahwa antara asupan lemak dengan kadar hsCRP pada mahasiswa yang tidak obes memiliki hubungan positif sangat lemah tetapi tidak bermakna.

\section{PEMBAHASAN}

Pada responden obes yang tinggal dengan orang tua hanya berjumlah 16 orang (53,3\%) dan tinggal di kost sebanyak 14 orang (46,7\%) dibandingkan dengan yang tidak obes jumlah responden yang tinggal dengan orang tua berjumlah 9 orang $(31,0 \%)$ dan yang tinggal di kost 20 orang (69\%). Ditinjau dari lingkungan tempat tinggal, sebagian besar responden tidak obes bertempat tinggal di kost, lingkungan tempat tinggal berpengaruh terhadap pemasukan energi, sebagian besar responden tidak obese bertempat tinggal dikost, hal ini membuat pola makan responden memilih makanan yang tinggi karbohidrat dan lemak serta rendah serat sehingga didapatkan kebanyakan responden yang obes adalah yang tinggal dikost. ${ }^{10}$ Hal ini tidak sesuai dengan penelitian Fitia Zulfa 2011 yang menyatakan bahwa terdapat hubungan antara remaja yang mengkonsumsi makanan tinggi karbohidrat dan lemak dengan kenaikan IMT, yaitu semakin tinggi konsumsi makanan tinggi karbohidrat dan lemak maka akan semakin tinggi pula status gizi. ${ }^{11}$

\section{Asupan lemak}

Rata-rata asupan lemak responden sebanyak $54.73 \mathrm{~g} \pm 54.00$ dengan data sebesar 89,8\% responden yang kekurangan asupan lemak dan $1.7 \%$ responden yang kelebihan asupan lemak. Hal ini bertentangan dengan hasil penelitian Inri 2011 menyatakan asupan lemak mahasiswa terbanyak adalah responden yang mempunyai asupan lemak cukup 41 orang (47,1\%) dan responden yang kekurangan asupan lemak sebanyak 19 orang (21,8\%). ${ }^{12}$ Kekurangan asupan lemak dapat berakibat kekurangan energi yang dihasilkan oleh tubuh, sehingga mengakibatkan orang tidak dapat berkonsentrasi dan energy tubuh akan menurun. Hal ini diakibatkan karena Lemak merupakan sumber energi padat tubuh, lemak menghasilkan $9 \mathrm{kkal} / \mathrm{gram}^{1}$ demikian pula jika orang mengalami kelebihan asupan lemak dimana konsumsi lemak total sehari yang baik adalah sebanyak 20-30\% dari total energi. Jika mengkonsumsi terutama lemak jenuh yang berlebih tentu tidak baik bagi kesehatan. Hal ini akan berisiko meningkatkan obesitas, penyakit degeneratif dan penyakit jantung koroner. ${ }^{13,14,15}$ Pada hasil penelitian yang dilakukan oleh Siti dkk, menyebutkan bahwa asupan lemak yang berlebihan berhubungan dengan kejadian hiperlipidemia pada anak Sekolah Menengah Pertama sedangkan pada penelitian yang dilakukan oleh Martlina menyebutkan bahwa asupan lemak yang tinggi berisiko 4,3 kali untuk mengalami hipertensi obesitik. ${ }^{16,17}$

Rata-rata asupan pada responden yang obes sebanyak 54,85 gram $\pm 21,34$ sedangkan pada tidak obes rata-rata asupan lemak sebanyak 54,89 gram $\pm 20,52$. Dapat disimpulkan bahwa rata-rata konsumsi lemak pada orang tidak obes lebih besar dibandingkan orang yang obes. Hal ini sejalan dengan penelitian yang dilakukan Elya Sugianti dkk tahun 2009 yang menyatakan bahwa orang yang mengalami obesitas sentral lebih tinggi jarang mengkonsumsi makanan berlemak. ${ }^{4}$ Hal ini diduga karena pada penelitian hanya diambil satu kali food recall 24 jam dan pada penelitian Elya Sugianti hanya ditanyakan frekuensi makanan berlemak dan tidak mengukur besarnya kontribusi energi dari makanan berlemak yang dikonsumsi sampel sehingga hasil yang diperoleh tidak menggambarkan kondisi konsumsi makanan berlemak sampel sebenarnya. ${ }^{4}$

\section{Kadar High Sensitivity C-Reaktive Protein}

High sensitive-C reactive protein 
adalah petanda biokimia untuk peradangan sistemik dari penyakit atherothrombotik, yang menunjukan hubungan dengan faktor penyakit kardiovaskular. Uji ini dapat mendeteksi proses inflamasi yang terjadi akibat pembentukan plak (aterosklerosis) dan dalam system pembuluh darah arteri, terutama arteri koroner. ${ }^{18}$ Hasil penelitian diperoleh kadar hs-CRP responden paling banyak ialah responden yang berisiko rendah $62,7 \%$ dan yang berisiko tinggi $13.6 \%$, dengan rata-rata kadar hs-CRP adalah sebesar $1.32 \mathrm{mg} / \mathrm{L}$. Melihat angka Angka rata-rata hs-CRP responden, mengindikasikan bahwa responden masuk dalam kelompok berisiko sedang (1,0-3,0 mg/L).

Perbedaan asupan lemak dan kadar High Sensitivity C-Reactive Protein (hsCRP) serum obes dan tidak obes serta Hubungan Asupan Lemak dengan Kadar High Sensitivity C-Reaktive Protein (hs-CRP)

Tidak terdapat perbedaan asupan lemak mahasiswa obes dengan mahasiswa tidak obes. Kadar High Sensitivity CReactive Protein (hs-CRP) serum pada obes dan tidak obes juga didapatkan hasil yang berbeda yaitu obes sebesar 37,78 $\mathrm{mg} / \mathrm{L}$ dan tidak obes sebesar 21,95 mg/L. Dari hasil tersebut dapat dikatakan bahwa obes mempunyai rerata kadar hs-CRP serum yang lebih tinggi dari kadar hs-CRP serum tidak obes. Hal ini sejalan dengan penelitian yang dilakukan oleh Susanto dan John 2009 yang menyatakan bahwa kadar hs-CRP yang tinggi lebih banyak terdapat pada orang obes. ${ }^{19}$ Hasil uji statistik menunjukan tidak terdapat hubungan yang bermakna antara asupan lemak dengan kadar hs-CRP pada mahasiswa Program Studi Kedokteran Umum Angkatan 20092012 Fakultas Kedokteran Universitas Sam Ratulangi baik pada mahasiswa obes dan mahasiswa tidak obes. Hal ini sejalan dengan penelitian Ms Anam pada tahun 2010 dimana tidak terdapat hubungan antara intervensi diet dengan kadar hs-CRP serum. ${ }^{20}$ hal serupa juga dikemukakan oleh Edward T.H. Yeh pada tahun 2003 yang menyakatakan bahwa kadar hs-CRP tidak dipengaruhi oleh intake makanan. ${ }^{21}$

\section{SIMPULAN}

Berdasarkan hasil penelitian dan pembahasan, diperoleh kesimpulan sebagai berikut:

1. Asupan lemak pada mahasiswa obes di Fakultas Kedokteran Universitas Sam Ratulangi Manado rata-rata sebanyak 58,85 gram $\pm 21,34$, dan mahasiswa tidak obes rata-rata sebanyak 54,89 gram $\pm 20,52$.

2. Kadar serum hs-CRP pada mahasiswa obes di Fakultas Kedokteran Universitas Sam Ratulangi rata-rata 2,01 mg/L $\pm 0,90$, dan mahasiswa tidak obes ratarata $0,62 \mathrm{mg} / \mathrm{L} \pm 0,70$.

3. Tidak terdapat perbedaan asupan lemak pada mahasiswa obes dengan non obes dan terdapat perbedaan kadar hs-CRP pada mahasiswa obes dengan tidak obes di Fakultas Kedokteran Universitas Sam Ratulangi.

4. Tidak terdapat hubungan antara asupan lemak dengan kadar hs-CRP pada mahasiswa obes dan tidak obes di Fakultas Kedokteran Universitas Sam Ratulangi.

\section{SARAN}

Saran untuk penelitian ini ialah:

1. Perlu adanya pengajaran tentang menu seimbang agar responden mengetahui dan bisa mengatasi kekurangan ataupun kelebihan asupan makanan.

2. Perlu ketelitian saat wawancara dengan responden dalam pengisian kuesioner.

3. Perlu dilakukan penelitian yang lebih lanjut tentang asupan lemak pada mahasiswa yang berhubungan dengan faktor-faktor lain yang mempengaruhi kadar High Sensitivity $C$ Reactive Protein (hs-CRP).

\section{UCAPAN TERIMAKASIH}

Ucapan terimakasih disampaikan kepada dr. Rianita MGizi, SpGK, Anita 
Basuki SKM, M.Kes. dan semua pihak yang baik secara ;angsung maupun tidak langsung telah menumbuhkan ide atau gagasan dalam pemikiran penulis sehingga dapat menyelesaikan artikel ini.

\section{DAFTAR PUSTAKA}

1. Almatsier S. Prinsip Dasar Ilmu Gizi. Jakarta: Penerbit Gramedia Pustaka, 2009; h.311,51,60.

2. Pamela RD. Overweight dan Obesitas sebagai suatu resiko penyakit degenerative. 2011.p.3

3. Basha Adnil. Management of Obesity in Cardiovascular Medicine. National Cardiovascular Center Harapan Kita [homepage on the Internet]. 2012 [cited 2012 Oct 25]. Available from: http://www. pjnhk.go.id.

4. Sugianti E, Hardinsyah, Afriansyah $\mathbf{N}$. Faktor resiko obesitas sentral orang dewasa di DKI Jakarta analisis lanjut data RISKESDAS 2007. Gizi Indon. 2009; 32(2):105,112.

5. Departemen Kesehatan RI. Profil data kesehatan Indonesia tahun 2011. Jakarta: Kementrian kesehatan Republik Indonesia; 2012.

6. Nursalim A, yuniadi Y. Paradox obesitas pada pasien gagal jantung. Jurnal kardiologi Indonesia. 2011:32(4);207.

7. Hatem EH, Ibraheim AA. High sensitivity C-reactive protein as a marker of cardiovascular risk in obese children an adolesencts. Jurnal kesehatan [serial online]. 2010 [cited 2012 Oct 26]; 2(9). Available from: http://www.scirp.org/ journal/health.

8. Dev Nirmita, Marcus SR. High sensitive C-reactive protein, an independent and early novel inflammatory marker in healthy obese women. Biomedical Research. 2012;23(1):73.

9. Soetardjo S. Gizi usia remaja. dalam Gizi seimbang Dalam Daur Kehidupan. Jakarta: Gramedia pustaka utama, 2011; p.332-3.

10. Barasi ME. At a glance Ilmu Gizi. Jakarta: Penerbit Erlangga, 2009; p.102-3.

11. Zulfa F. Hubungan kebiasaan konsumsi fast food modern dengan status gizi (BB/TB Z-score) di SD Al-muttaqin tasikmaya. Prosiding seminar nasional peran kesehatan masyarakat dalam pencapaian MDG's di Indonesia; 2011 April 12; Jakarta: FKM-UNSIL; 2011.

12. Suganti E. Faktor resiko obesitas sentral pada orang dewasa di Sulawesi utara, Gorontalo dan DKI Jakarta [Skripsi]. Bogor: Fakultas Ekologi Manusia; 2009.

13. Sigarlaki IE. Hubungan antara asupan lemak dengan status IMT mahasiswa program studi kedokteran umum Universitas Sam Ratulangi [Skripsi]. Manado: FK Unsrat; 2012.

14. Guyton AC, Hall JE. Buku Ajar Fisiologi Kedokteran (Edisi 11). Jakarta: EGC, 2008; p.917.

15. Deghan Mashid, Danesh Noori A. Childhood obesity prevalence and prevention. Nutrition journal. 2005:4;24:3.

16. Hidayati SN, Hadi $H$, Lestariana $W$. Hubungan asupan zat gizi da indeks massa tubuh dengan hiperlipidemia pada murid SLTP yang obesitas di Yogyakarta. Sari pediatri. 2006;8(1):30.

17. Tri KM, Sulchan M. High fat intake and sport activity as risk factors of obesity hypertension in early adolescence. Jurnal Of Nutrition Collage. 2012;1(1):175.

18. Kee JL. Pedoman pemeriksaan laboratorium dan diagnosis. Jakarta: Penerbit buku kedokteran EGC, 2008; p.146

19. HK Susanto, Adam JMF. Plasminogen activator inhibitor-1 and high sensitivity creactive protein in obesity. The Indonesian Journal Of Medical Science. 2009; 2(1):27,29.

20. Anam, MS. Pengaruh inervensi diet dan olahraga terhadap indeks massa tubuh, kesegaran jasmani, hs-CRP dan profil lipid pada anak obesitas [Tesis]. Semarang: Fakultas Kedokteran Universitas Diponegoro; 2010.

21. Yeh ETH, Willerson JT. Coming of age of C-Reactive Protein using inflammation markers in cardiology. Circulation. 2003; 370-2. 